Discussion Paper No. 730

\title{
THE KEYNESIAN MULTIPLIER EFFECT RECONSIDERED
}

\author{
Yoshiyasu Ono
}

January 2009

The Institute of Social and Economic Research

Osaka University

6-1 Mihogaoka, Ibaraki, Osaka 567-0047, Japan 
December 2008

\title{
The Keynesian Multiplier Effect Reconsidered
}

\author{
by \\ Yoshiyasu Ono* \\ Osaka University
}

\begin{abstract}
The Keynesian multiplier effect is reinterpreted and several issues that may have misled assessments of the effect of fiscal spending are discussed. It is shown that even in the textbook Keynesian framework some transfer policy 'reduces' aggregate demand and that public works spending may completely crowd out private consumption. Useless public works are found to be equivalent to transfers although they increase accounting national income more than transfers do. The net effect of fiscal spending on national benefits is explored and shown to equal only the direct benefit created by the spending.
\end{abstract}

JEL classification: E12, E62, E01

Keywords: the multiplier effect, public works, unemployment benefits, national income accounting.

Address: Institute of Social and Economic Research, Osaka University, 6-1, Mihogaoka, Ibaraki, Osaka, 567-0047, JAPAN

* This is a substantially revised version of ISER Discussion Paper No.0673, October 2006. I am indebted to M. Ogaki for his very stimulative suggestion. Comments and suggestions by H. Kojima, N. Matsushima, K. Takii and A. Shibata are particularly valuable. I also thank C. Freedman, S. Ikeda, J. Itaya, R. Murota, K. Ogawa and Y. Sugimoto for discussions. This research is financially supported by the Grants-in-Aid for Scientific Research, JSPS, Japan. 
Facing the financial crisis triggered by the US subprime loan problem in 2008, many countries, including the USA, EU countries and Japan, have started to reaffirm the importance of fiscal expansion. Since the neoclassical macroeconomics takes it as yielding crowding out and gives no reason that supports it as a stimulus, most policy makers still rely on the conventional Keynesian multiplier model as a theoretical basis. This paper reinterprets the implication of the multiplier effect and discusses some issues that may have misled understanding of it.

By extending the multiplier model to the case where there are people with different marginal propensities to consume this paper shows that public works spending may completely crowd out private consumption even in the standard Keynesian setting. Government transfers, such as unemployment relief expenditure, lump-sum benefits adopted by Japan's K. Obuchi administration in 1999, and tax rebates implemented by the US G. Bush administration in 2001, are shown to be equivalent to useless public works. ${ }^{1}$ It is also found that the benefit of public works spending tends to be exaggerated under the present national accounting.

\section{Reinterpreting the Multiplier Effect}

This section starts the analysis by replicating the Keynesian multiplier effect, where private investment is ignored for simplicity. Since disposable income $Y_{d}$ equals revenues from fiscal spending $G$ and consumption demand $C$ minus tax payments $T$,

$$
Y^{d}=G+C-T
$$

consumption $C$ satisfies

$$
C=F(G+C-T),
$$

where $F($.$) represents the consumption function. { }^{2}$ Note that (1) is valid whether fiscal spending $G$ implies government purchases or transfers. National Income $Y$ is then

$$
Y=\alpha G+C,
$$

where

$$
\begin{aligned}
& \alpha=1 \text { for government purchases, } \\
& \alpha=0 \text { for transfers. }
\end{aligned}
$$

(1) and (2) reproduce the standard multiplier effect:

\footnotetext{
1 The T. Aso administration in Japan also proposes uniform benefits in 2008.

${ }^{2} F($.) is used so as to distinguish between consumption level $C$ and the consumption function.
} 


$$
\mathrm{d} Y / \mathrm{d} G=\alpha+\mathrm{d} C / \mathrm{d} G
$$

where

$$
\begin{aligned}
& \mathrm{d} C / \mathrm{d} G=F^{\prime} /\left(1-F^{\prime}\right) \text { under a loan budget, } \\
& \mathrm{d} C / \mathrm{d} G=\mathrm{d} C /\left.\mathrm{d} G\right|_{\mathrm{d} T=\mathrm{d} G}=0 \text { under a balanced budget. }
\end{aligned}
$$

The first term of (4), $\alpha$, is interpreted as the government demand effect. It is the direct effect of fiscal spending on income and hence satisfies (3). The second term, $\mathrm{d} C / \mathrm{d} G$, is interpreted as the transfer effect. It exhibits the effect on household consumption provoked by fiscal payments. Note that there is no difference in the transfer effect between unemployment benefits, public works, government purchases and so on since household behavior is the same after the payments are received. It only depends on the distribution of the payments.

In order to explore the implication of the transfer effect, (5) is modified so that it can treat the case where there are two groups of people and their marginal propensities to consume differ from each other. Let $F_{i}$ represent the consumption function of group $i$ (for $i=1,2$ ), aggregate consumption $C$ is

$$
C=F_{1}\left(\sigma_{1} C+G_{1}-T_{1}\right)+F_{2}\left(\sigma_{2} C+G_{2}-T_{2}\right), \text { where } \sigma_{1}+\sigma_{2}=1 .
$$

$\sigma_{i}, G_{i}$ and $T_{i}$ respectively denote group $i$ 's share of income generated by consumption demand $C$, fiscal spending paid to group $i$, and taxes imposed on group $i$. Without loss of generality we assume

$$
1 \geq F_{1}^{\prime}>F_{2}^{\prime} \geq 0,
$$

where group 2 is naturally considered to be richer than group 1. From (6),

$$
\mathrm{d} C=\left[F_{1}{ }^{\prime} \mathrm{d}\left(G_{1}-T_{1}\right)+F_{2}{ }^{\prime} \mathrm{d}\left(G_{2}-T_{2}\right)\right] /\left\{1-\left[\sigma_{1} F_{1}{ }^{\prime}+\left(1-\sigma_{1}\right) F_{2}{ }^{\prime}\right]\right\},
$$

where $\mathrm{d}\left(G_{i}-T_{i}\right)$ stands for an increase in group $i$ 's net receipt from fiscal spending. From (7) and (8), fiscal spending distributed to the poorer has a larger stimulative effect on aggregate consumption $C$ than that to the richer.

Fiscal spending may even reduce aggregate consumption under a balanced budget:

$$
\mathrm{d} G-\mathrm{d} T=\mathrm{d}\left(G_{1}-T_{1}\right)+\mathrm{d}\left(G_{2}-T_{2}\right)=0 .
$$

In fact, (7) and (8) then give

$$
\begin{gathered}
\mathrm{d} C /\left.\mathrm{d}\left(G_{1}-T_{1}\right)\right|_{\mathrm{d} T=\mathrm{d} G}=\left(F_{1}{ }^{\prime}-F_{2}{ }^{\prime}\right) /\left\{1-\left[\sigma_{1} F_{1}{ }^{\prime}+\left(1-\sigma_{1}\right) F_{2}{ }^{\prime}\right]\right\}>0, \\
\mathrm{~d} C /\left.\mathrm{d}\left(G_{2}-T_{2}\right)\right|_{\mathrm{d} T=\mathrm{d} G}=-\left(F_{1}{ }^{\prime}-F_{2}{ }^{\prime}\right) /\left\{1-\left[\sigma_{1} F_{1}{ }^{\prime}+\left(1-\sigma_{1}\right) F_{2}{ }^{\prime}\right]\right\}<0 .
\end{gathered}
$$

Since a pure transfer yields no government demand, i.e., $\alpha=0$ as shown in (3), from (2) and (9), a net redistribution from the poorer to the richer reduces aggregate consumption $C$ and national income $Y$. Unemployment compensation is a typical reverse example. Moreover, if the 
people of group 1 are unemployed $\left(\sigma_{1}=0\right)$ and spend all additional income on consumption $\left(F_{1}{ }^{\prime}=1\right)$, from (7) and (9)

$$
\mathrm{d} C /\left.\mathrm{d}\left(G_{2}-T_{2}\right)\right|_{\mathrm{d} T=\mathrm{d} G}=-1 \quad \text { if } \sigma_{1}=0 \text { and } F_{1}{ }^{\prime}=1,
$$

i.e., if the government reduces unemployment benefits and redistributes the fund to the employed, aggregate consumption $C$ and national income $Y$ decrease by the amount of redistribution. Intuitively, since only people in group 2 are employed and hence the multiplier is $1 /\left(1-F_{2}{ }^{\prime}\right)$, a decrease in the income of the unemployed yields a negative transfer effect of which the magnitude is $-F_{1}{ }^{\prime} /\left(1-F_{2}{ }^{\prime}\right)$, where $F_{1}{ }^{\prime}=1$, while an increase in the income of the employed yields a positive transfer effect of which the magnitude is $F_{2}{ }^{\prime} /\left(1-F_{2}{ }^{\prime}\right)$. Thus, the total effect equals -1 . Note that this property holds for any $F_{2}{ }^{\prime}$ that satisfies (7).

From (3), (4) and (9), it is also shown that the multiplier effect of government purchases can be less than 1 . In particular, if the government reduces unemployment benefits and expands commodity purchases, i.e.,

$$
\mathrm{d} T_{1}=\mathrm{d} T=\mathrm{d} G=\mathrm{d} G_{2}, \quad \mathrm{~d} T_{2}=\mathrm{d} G_{1}=0,
$$

then from (10)

$$
\mathrm{d} C / \mathrm{d} G=\mathrm{d} C /\left.\mathrm{d}\left(G_{2}-T_{2}\right)\right|_{\mathrm{d} T=\mathrm{d} G}=-1 .
$$

Therefore, from (2) and (3),

$$
\mathrm{d} Y / \mathrm{d} G=1+\mathrm{d} C / \mathrm{d} G=0,
$$

i.e., the multiplier effect on national income $Y$ is zero. Unemployed people decrease consumption and the government increases it by just that much.

In sum, the estimated income multiplier can be either negative or positive. This may be why the effects on GDP of various fiscal expenditures are found to be significantly different in the literature, depending on the composition of fiscal spending. ${ }^{3}$ The pattern of distribution among different income classes that have different marginal propensities to consume is quite important when comparing the demand-side effects of various fiscal expenditures on GDP, while the difference of the purpose of fiscal spending, e.g., productive vs. non-productive expenditures, current vs. capital expenditures, etc., is important on the supply side. ${ }^{4}$

\footnotetext{
${ }^{3}$ Gupta et al. (2005) give an extensive survey of the literature on this issue.

${ }^{4}$ Aschauer (1989) shows that public expenditures on nonmilitary public capital contribute to productivity significantly more than those on military capital. Devarajan, Swaroop and Zou (1996) find that in developing countries current expenditures stimulate growth more than capital expenditures and conclude that those countries may spend too much on public capital.
} 


\section{Benefit of Fiscal Spending}

The transfer effect exhibits not only the magnitude of demand creation but also the actual benefit that people receive from consumption since they spend income on consumption after recognizing it as worthy. In contrast, the government demand effect does not necessarily represent actual benefits since fiscal spending is not determined on the utility basis. This section returns to the original model, where (5) is valid, and examines the effects of various types of fiscal spending on national benefit $B$.

Let $\theta$ denote the direct benefit-cost ratio of fiscal spending, total benefit $B$ is

$$
B=\theta G+C,
$$

and the multiplier effect on total benefit $B$ is

$$
\mathrm{d} B / \mathrm{d} G=\theta+\mathrm{d} C / \mathrm{d} G,
$$

where $\mathrm{d} C / \mathrm{d} G$ is given by (5). If fiscal spending $G$ is a transfer payment, such as unemployment benefits and tax rebates, $\theta$ equals zero and hence the effect on total benefit $B$ consists of only the transfer effect, as is consistent with (3) and (4). In the case of useless public works $\theta$ again equals 0 . Therefore, useless public works are equivalent to unemployment benefits, although in the standard multiplier theory they are considered to be more stimulative than unemployment benefits since they create demand. ${ }^{5}$

The equivalence between unemployment benefits and useless public works is intuitively explained as follows. Unemployment benefits are directly paid to unemployed people without making them work. In the case of useless public works the government hires them, makes them do nothing substantial and pays salaries to them. Thus, these two are the same except for the pretext of the payment, viz. unemployment benefits or salaries. ${ }^{6}$ The same logic applies to the case in which some commodities, e.g. concrete, are purchased. Concrete is produced of gravel and limestone and the payment is distributed to miners and haulers -i.e., purchasing concrete is equivalent to paying unemployment benefits to them.

The multiplier effect of public works spending (or government purchases) is shown to be larger than that of a transfer payment by (3) and (4) since not the benefit, but the amount, of spending is focused on. ${ }^{7}$ The national accounting system follows such convention and public

\footnotetext{
${ }^{5}$ See Keynes (p.127, 1936) and the textbook by Itoh (2001, p.61) for such statements.

${ }^{6}$ They are equivalent also from the viewpoint of distribution in the present example.

${ }^{7}$ Alesina and Perotti (1997), Alesina et al. (1998), Kneller et al. (1999) and von Hagen and Strauch (2001) empirically examine fiscal consolidations in OECD countries and find that reductions in transfers tend to be more
} 
works spending is in its entirety added to national income regardless of its benefit, whereas a transfer payment is not counted. Thus, the effect of public works spending tends to be exaggerated. ${ }^{8}$ The conventional result is valid on the benefit basis only if fiscal spending creates the same benefit as the cost (i.e., $\theta=1$ ). Even if not so, however, public works spending is still more beneficial than a transfer payment as long as it yields some direct benefit $(\theta>0)$.

\section{Some Extensions and Conclusion}

In the absence of fiscal illusion the Ricardian equivalence holds and disposable income $Y^{d}$ must be calculated on the permanent basis, implying that $T=G$ in (1). From (5), the transfer effect (except the redistribution effect given by (9)) is null and only the government demand effect arises, whether under a balanced budget or a loan budget. Therefore, from (4) and (11),

$$
\mathrm{d} Y / \mathrm{d} G=1, \mathrm{~d} B / \mathrm{d} G=\theta,
$$

i.e., the effect of government purchases on accounting national income is 1 whereas the effect on national benefit equals the benefit directly created by them.

In the presence of fiscal illusion the transfer effect, $\mathrm{d} C / \mathrm{d} G$, is given by the first equation of (5) under a loan budget. In this case, however, the fiscal deficit must be redeemed in the future and then a negative transfer effect with the same present-value magnitude arises. Thus, after cancelling out the costs and benefits intertemporally we come to a quite simple conclusion:

“The net effect of fiscal spending on national benefit consists of its direct benefit and the redistribution effect only, regardless of the budget system or the type of

fiscal spending.”

Transfer payments and useless public works yield only the redistribution effect, which can be either positive or negative.

There are still some aspects that are ignored here. If there is some disutility of working, useless public works are inferior to transfers. ${ }^{9}$ Another difference arises through the inflation effect. Public works create new labor demand and reduce the deflationary gap in the labor

successful than reductions in public investment --i.e., the former contract national income less than the latter. Gupta et al. (2005) show the same tendency in developing countries.

\footnotetext{
${ }^{8}$ Kuznets (1948) expresses concern about the part of government purchases in national income accounting from another viewpoint. Although they are uniformly regarded as final consumption, in reality they may be used for intermediate goods and then are duplicated in calculating national income.

${ }^{9}$ Keynes (p.128, 1936) states that labor may have a positive utility for people who have been long unemployed, which makes public works superior to transfers.
} 
market while transfers do not. The reduction in deflation makes it less advantageous for consumers to hold money than to consume and hence stimulates consumption. ${ }^{10}$ Anyway, these factors are not taken into account in the conventional Keynesian framework.

\section{REFERENCES}

Alesina, A., and R. Perotti. (1997) "Fiscal Adjustments in OECD Countries: Composition and Macroeconomic Effects.” IMF Staff Papers, 92, 571-89.

Alesina, A., R. Perotti, and J. Tavares. (1998) “The Political Economy of Fiscal Adjustments.” Brookings Papers on Economic Activity, 1, 197-248.

Aschauer, D. A. (1989) “Is Public Expenditure Productive?” Journal of Monetary Economics, 23, 177-200.

Devarajan, S., V. Swaroop and H. Zou. (1996) “The Composition of Public Expenditure and Economic Growth.” Journal of Monetary Economics, 37, 313-44.

Itoh, M. (2001) Nyumon Keizaigaku (Introductory Economics), 2nd edition. Tokyo: Tokyo: Nihon Hyoronsha.

Gupta, S., B. Clements, E. Baldacci and C. Mulas-Granados. (2005) "Fiscal Policy, Expenditure Composition, and Growth in Low-income Countries.” Journal of Internationl Money and Finance, 24, 441-63.

Keynes, John M. (1936) The General Theory of Employment, Interest and Money. London: Macmillan.

Kneller, R., M. Bleaney and N. Gemmell. (1999) “Fiscal Policy and Growth: Evidence from OECD Countries.” Journal of Public Economics, 74, 171-90.

Kuznets, S. (1948) “National Income: A New Version.” Review of Economics and Statistics, 30, $105-24$.

Ono, Y. (1994) Money, Interest, and Stagnation. Oxford, UK: Clarendon Press.

Ono, Y. (2001) “A Reinterpretation of Chapter 17 of Keynes’s General Theory: Effective Demand Shortage Under Dynamic Optimization.” International Economic Review, 42, 207-36.

von Hagen, J., and R. Strauch (2001) "Fiscal Consolidations: Quality, Economic Conditions, and Success.” Public Choice, 109, 327-46.

\footnotetext{
${ }^{10}$ See Ono $(1994,2001)$ for this effect of public works spending in the steady state with persistent stagnation.
} 